\title{
Biomimetic Strategies for the Glioblastoma Microenvironment
}

\author{
Junghwa Cha and Pilnam Kim* \\ Department of Bio and Brain Engineering, Korea Advanced Institute of Science and Technology, Daejeon, South Korea
}

Glioblastoma multiforme (GBM) is a devastating type of tumor with high mortality, caused by extensive infiltration into adjacent tissue and rapid recurrence. Most therapies for GBM have focused on the cytotoxicity and have not targeted GBM spread. However, there have been numerous attempts to improve therapy by addressing GBM invasion, through understanding and mimicking its behavior using three-dimensional (3D) experimental models. Compared with two-dimensional models and in vivo animal models, 3D GBM models can capture the invasive motility of glioma cells within a 3D environment comprising many cellular and non-cellular components. Based on tissue engineering techniques, GBM invasion has been investigated within a biologically relevant environment, from biophysical and biochemical perspectives, to clarify the pro-invasive factors of GBM. This review discusses the recent progress in techniques for modeling the microenvironments of GBM tissue and suggests future directions with respect to recreating the GBM microenvironment and preclinical applications.

\section{OPEN ACCESS}

Edited by:

Sara Pedron,

University of Illinois at UrbanaChampaign, United States

Reviewed by:

Triantafyllos Stylianopoulos, University of Cyprus, Cyprus Julien Georges Didier Barthès,

Protip Medical, France

*Correspondence:

Pilnam Kim

pkim@kaist.ac.kr

Specialty section:

This article was submitted to Biomaterials,

a section of the journal

Frontiers in Materials

Received: 29 October 2017 Accepted: 06 December 2017 Published: 19 December 2017

Citation:

Cha J and Kim P (2017) Biomimetic Strategies for the Glioblastoma Microenvironment. Front. Mater. 4:45. doi: 10.3389/fmats.2017.00045
Keywords: glioblastoma, invasion, in vitro three-dimensional model, microenvironment, biomimetic scaffolds

\section{INTRODUCTION}

Malignant glioma, which is the most common primary brain tumor in adults, arises from star-shaped glial cells or their precursors within the central nervous system (Louis, 2006). Clinically, the World Health Organization grading system classifies gliomas into four stages. Of these, the most aggressive grade IV astrocytoma, glioblastoma multiforme (GBM); this tumor is the most devastating to health and cannot be cured (Louis et al., 2016). One of the main reasons why GBMs are incurable is that they spread widely within intracranial spaces, resulting in an indistinct tumor margin that prevents complete resection (Stummer et al., 2006). Unlike other systemic tumors, GBM rarely metastasizes beyond the central nervous system (Holland, 2000). GBM usually arises from the cerebrum and is prone to micrometastasis, i.e., infiltration at a single-cell level throughout the brain parenchyma, as well as across the corpus callosum from one hemisphere to the other, thus producing a bilateral butterfly like glioma (Dziurzynski et al., 2012). Although GBM invasion is confined within the intracranial spaces, the prognosis of the patients with GBM is still bleak.

The standard therapy for GBM is a surgical resection followed by a combination of radiotherapy and chemotherapy. Typically, postoperative radiotherapy is given along with the alkylating agent temozolomide (Stupp et al., 2005). Unfortunately, GBM cells are very resistant to these conventional therapies, and most patients with GBM end up developing recurrent tumors (Yip et al., 2009). Targeted therapy to overcome the low efficacy and high toxicity of postsurgical adjuvant therapies mostly focuses on treating proliferative cells, not invading cells (Wang et al., 2015). To achieve greater therapeutic efficacy, targeting the infiltration of GBM could be beneficial. Therefore, it is important to understand GBM invasion in brain tissue, to predict and evaluate tumor cell behavior; this is essential for developing new therapeutic inventions. Since GBM cells are predominantly regulated by the complex microenvironment and cause dynamic remodeling of their surroundings that facilitates 
invasion (Rao, 2003), it is necessary to investigate the influence of the microenvironment of the brain to understand the unique features of GBM invasion. By reproducing both the composition and structural elements of the complex in vivo tumor microenvironment, the pro-invasive factors for GBM cells could be identified in pathophysiologically relevant context, which may eventually lead to novel therapeutic options for clinical trials.

This review focuses on recent research for biomimetic approaches to develop in vitro three-dimensional (3D) tumor models of glioblastoma cell invasion. First, the compositional and structural features of brain tumor microenvironment are introduced. Then, state-of-the-art experimental models of GBM invasion are presented and new approaches to mimic the brain microenvironment are discussed. Finally, future directions with respect to constructing in vivo-like tumor models for glioblastoma are suggested.

\section{BRAIN TUMOR MICROENVIRONMENT}

Brain tumor tissue comprises heterogeneous subpopulations of tumor cells intermingling with normal parenchymal cells (Hambardzumyan and Bergers, 2015). In addition to cellular components, non-cellular components such as brain extracellular matrix (ECM) and brain anatomy play crucial roles in GBM malignancy (Gritsenko et al., 2012). As pro-migratory, proinvasive factors, these chemical and physical factors facilitate the GBM progression (Figure 1). By understanding the pro-invasive components within GBM microenvironment, we could recreate the in vivo behaviors of GBM cells.

\section{Anatomical Features in Glioma Tissue}

The unique anatomical structures in the brain include white matter tracts and capillaries, called Scherer's structures (Cuddapah

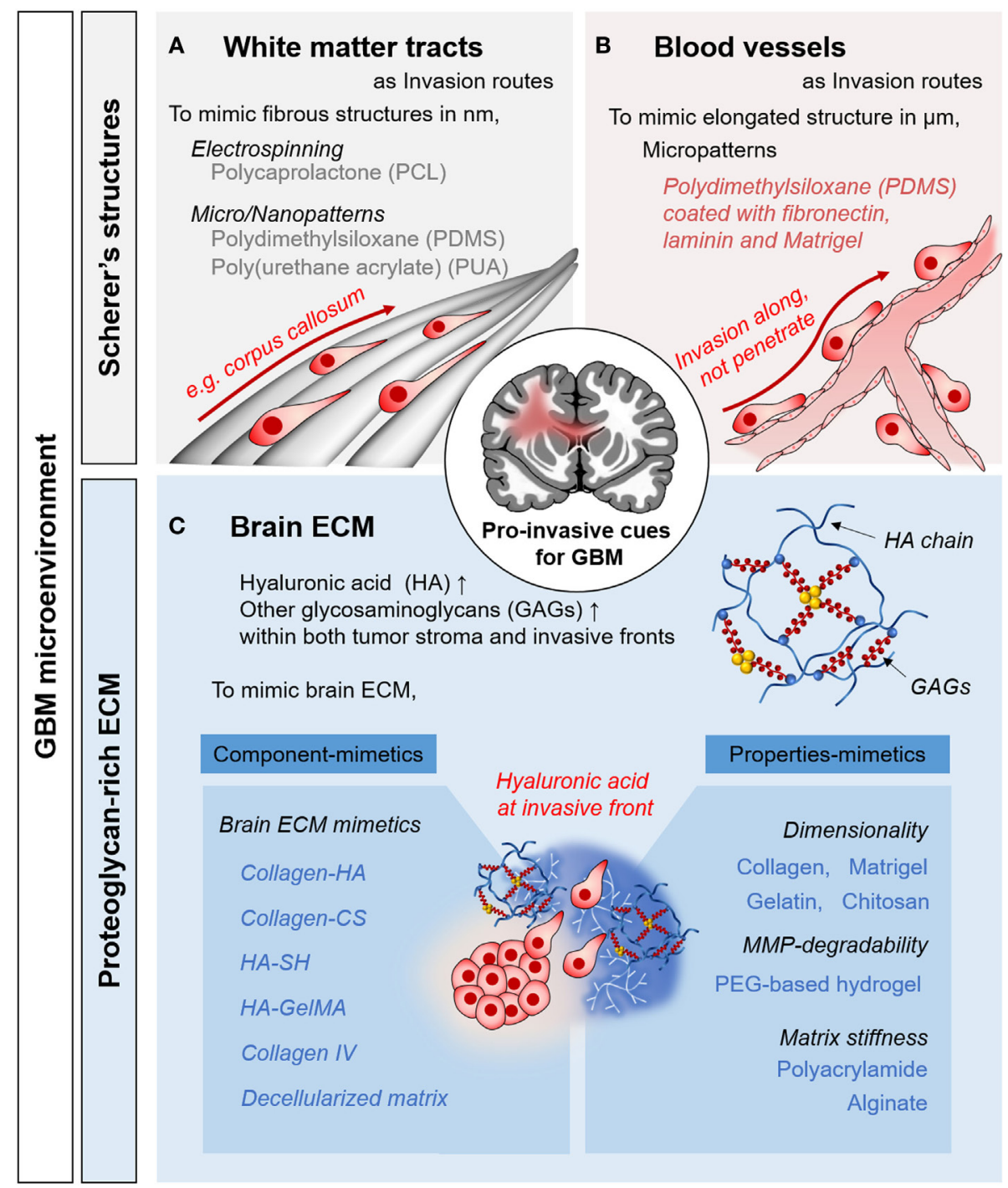

FIGURE 1 | Pro-invasive cues in glioblastoma multiforme (GBM) microenvironments and in vitro approaches to mimic the microenvironmental cues. Representative examples of Scherer's structures: white matter tract (A) and blood vessels (B). (C) Proteoglycan-rich extracellular matrix (ECM) in tumorous brain tissue. 
et al., 2014). A white matter tract is a bundle of aligned axons. These are bound manly in corpus callosum, in which fibrous structures consist of submicron-sized fibers. For pro-invasive characteristics, topography is a major mechano-physical cue derived from the ECM structure and the anatomical features or organs, which play key roles in cellular behavior and function (Friedl and Alexander, 2011). Histological observations have revealed that single GBM cells preferentially migrate to these structures (Bellail et al., 2004; Louis, 2006). As biophysical cues for pro-invasive characteristics, tumor cells interact with this existing brain anatomy, which is an important mechanism of invasion by GBM cells.

\section{ECM in Glioma Tissue}

The normal brain lacks the stiff fibrillar collagen matrix that is typical component in other organs (Bellail et al., 2004). The brain has a substantially different ECM, composed of glycosaminoglycans (GAGs), proteoglycans (PGs), and other glycoproteins (Cuddapah et al., 2014; Rao et al., 2014; Miyata and Kitagawa, 2017). The interstitial spaces in the brain parenchyma are filled with a PG-based matrix, which interacts with hyaluronic acid (HA)-binding proteins (e.g., CD44 and RHAMM) and tenascins (Gladson, 1999). By contrast, fibrous, adhesive ECM proteins, such as collagen, laminin, and fibronectins, are rarely found in the brain parenchyma, where their expression is restricted to the basement membrane of neural vasculature (Lau et al., 2013). These ECM components function as components of blood-brain barrier, which constitutes both a chemical and physical barrier, inducing the formation of tight junctions.

The composition of the ECM of glioma tissue is distinct from that of normal tissue. During cancer progression, the secretion of neural ECM molecules is increased significantly. The amorphous ECM at the invasive front of a proliferating GBM strongly expresses GAGs and PGs, especially HA (Bellail et al., 2004; Jin et al., 2009). Moreover, fibrous, adhesive ECM proteins such as collagen IV, fibronectin, and laminin are strongly upregulated (Gladson, 1999). Increased production of tumorous ECM leads to a significant increase in its volume, contributing to elevated interstitial pressure in the confined extracellular space (Munson et al., 2013). In addition to acting as a signaling molecule, tumorous ECM activates tumor-associated pathways, promoting cell survival and motility (Rape et al., 2014).

\section{IN VITRO 3D GBM MODELS}

There are several advantages of utilizing in vitro 3D GBM models to investigate the effects of the microenvironment on GBM invasion. Unlike two-dimensional (2D) models, in vitro 3D GBM models can replicate the highly complex microenvironment of in vivo GBM niches. Furthermore, well-defined 3D in vitro GBM niches are simpler and more reliable than in vivo animal models, which involve costly, time-consuming technical procedures (Xiao et al., 2017). Here, we presented an overview of the biomimetic approaches for reconstructing in vitro 3D GBM models of anatomical and matrix-related aspects of the GBM microenvironment (see also Table 1).

\section{Fibrous Scaffold-Based Culture Models}

Histological evidence indicates that GBM cells migrate along pre-existing brain structures and form Scherer's structures by interacting with the neural microenvironment. Brain anatomy, including the brain parenchyma, pre-existing blood vessels, white matter tracts, and the subarachnoid space below the meningeal covering of the brain, plays an important role in GBM invasion (Cuddapah et al., 2014).

To mimic these invasion routes, several synthetic polymerbased micro/nanotechnologies have been used to investigate the behavior of GBM cells. Recently, there have been reports on the effect of 2D topography on GBM invasion, replicating the in vivo behavior of GBM cells (Cha et al., 2015; Smith et al., 2016; Sim et al., 2017). For instance, using 2D polydimethylsiloxane (PDMS) substrates, the tapered microtract of the gradient width ranging from 3 to $100 \mu \mathrm{m}$ was fabricated to identify the effect of topography on GBM motility (Cha et al., 2015). For microtracts smaller than $3 \mu \mathrm{m}$, micropatterns can induce in vivo-like saltatory migration, even on $2 \mathrm{D}$ surfaces. In addition, polyurethane acrylate-based nanotopography (Smith et al., 2016) and nanofabricated polystyrene (Zhu et al., 2004) closely mimic the fibrillar structures of brain.

Techniques to fabricate nanofibers, such as electrospinning, have been used to mimic the delicate fibrous structures of the white matter tracts (Johnson et al., 2009; Agudelo-Garcia et al., 2011; Rao et al., 2013b; Sharma et al., 2013; Beliveau et al., 2016; Cha et al., 2016). The behavior of glioma cells on nanofibers was observed to be a function of substrate topography, as GBM cells migrated much faster on aligned fibers than on random fibers (Johnson et al., 2009; Beliveau et al., 2016). This in vivo-like behaviors of glioma cells is associated with STAT3 signaling, a driver of malignancy during GBM progression (Agudelo-Garcia et al., 2011). Modification of both biochemical and biophysical features of nanofibers has a significant effect on GBM migration (Rao et al., 2013b; Sharma et al., 2013), emphasizing the importance of biomimetic approaches to understanding the behaviors of glioma.

\section{Matrix Scaffold-Based Culture Models}

To simulate tumorous ECM components in brain, researchers have attempted to reconstruct an HA-rich environment and GAG-based matrices. The biophysical properties of the ECM matrix have also been reported to influence GBM cell invasion; thus, numerous studies have examined the effects of matrix dimensionality, degradability, and stiffness.

\section{Matrices to Mimic the ECM Properties}

In addition to the brain anatomy, the brain ECM also has biophysical effects on GBM invasion. To provide the effects of $3 \mathrm{D}$ cell-ECM interaction on GBM invasion, naturally derived biomaterials, such as Matrigel (Jin et al., 2009) and collagen (Yang et al., 2010), have been used to develop a 3D ECM microenvironment for GBM. Irrelevant components of the brain ECM, such as chitosan-alginate hydrogels (Kievit et al., 2010) and collagen-agarose hydrogels (Ulrich et al., 2010), were chosen because they have a biologically inert to investigate biophysical effects of the matrices solely, resulting in a mechanosensitive 
GBM invasion response. When designing matrices, their physical properties, such as degradability, stiffness, and pore sizes, are usually interconnected and thus influenced each other. Therefore, studies controlling designing parameters, such as the physical properties of matrix metalloprotease (MMP)degradable polyethylene glycol gels (Wang et al., 2014, 2017), gelatin methacrylate (GelMA) (Pedron and Harley, 2013), and polyacrylamide (Ulrich et al., 2009; Rape and Kumar, 2014;

TABLE 1 | Representative approaches used to mimic glioblastoma multiforme (GBM) microenvironment.

To mimic Scherer's structures

\begin{tabular}{|c|c|c|c|c|c|}
\hline & Biomaterials & Techniques & Cells & Findings & Reference \\
\hline \multirow{2}{*}{$\begin{array}{l}\text { Effects of } \\
\text { anatomic } \\
\text { topography }\end{array}$} & $\begin{array}{l}\text { Polydimethylsiloxane } \\
\text { (PDMS) }\end{array}$ & $\begin{array}{l}\text { Soft lithography-based } \\
\text { micropatterning }\end{array}$ & U87, U251 & $\begin{array}{l}\text { Effective topography to induce } \\
\text { saltatory migration }\end{array}$ & $\begin{array}{l}\text { Cha et al. } \\
(2015)\end{array}$ \\
\hline & $\begin{array}{l}\text { Polyurethane } \\
\text { acrylate }\end{array}$ & $\begin{array}{l}\text { UV-assisted capillary } \\
\text { force lithography }\end{array}$ & $\begin{array}{l}\text { Patient-derived } \\
\text { GBM cells }\end{array}$ & $\begin{array}{l}\text { Mimicry of in vivo three-dimensional (3D) } \\
\text { migration, PDGF-sensitive response }\end{array}$ & $\begin{array}{l}\text { Smith et al. } \\
(2016)\end{array}$ \\
\hline \multirow[t]{5}{*}{$\begin{array}{l}\text { Fibrous structure } \\
\text { of white matter } \\
\text { tract }\end{array}$} & $\begin{array}{l}\text { Polycaprolactone } \\
\text { (PCL) }\end{array}$ & Electrospinning & $\begin{array}{l}\text { U251, X12, } \\
\text { neurosphere } \\
\text { glioma from } \\
\text { biopsy }\end{array}$ & $\begin{array}{l}\text { Effects of fiber directionality on } \\
\text { glioma migration }\end{array}$ & $\begin{array}{l}\text { Johnson et al. } \\
\text { (2009) }\end{array}$ \\
\hline & PCL & Electrospinning & $\begin{array}{l}\text { Dissociated } \\
\text { U87, U251, } \\
\text { GBM-derived } \\
\text { tumor initiating } \\
\text { cells (G8, G9) }\end{array}$ & $\begin{array}{l}\text { Involvement of STAT3 signaling in } \\
\text { topography-induced glioma migration }\end{array}$ & $\begin{array}{l}\text { Agudelo-Garcia } \\
\text { et al. (2011) }\end{array}$ \\
\hline & PCL & Electrospinning & $\begin{array}{l}\text { Patient-derived } \\
\text { GBM cells } \\
\text { (GSC11) }\end{array}$ & $\begin{array}{l}\text { Invasion preference along the } \\
\text { fibrous structures }\end{array}$ & $\begin{array}{l}\text { Cha et al. } \\
\text { (2016) }\end{array}$ \\
\hline & Polystyrene & $\begin{array}{l}\text { Spinneret-based } \\
\text { Tunable Engineered } \\
\text { Parameters (STEP) }\end{array}$ & DBTRG-05MG & $\begin{array}{l}\text { Effects of nanofibers on glioma } \\
\text { migration and blebbing dynamics }\end{array}$ & $\begin{array}{l}\text { Sharma et al. } \\
\text { (2013) }\end{array}$ \\
\hline & $\begin{array}{l}\text { PCL, gelatin-PCL, } \\
\text { PDMS-PCL, PES-PCL, } \\
\text { PCL-collagen, PCL- } \\
\text { HA, PCL-matrigel }\end{array}$ & $\begin{array}{l}\text { Core-shell } \\
\text { electrospinning }\end{array}$ & $\begin{array}{l}\text { Patient-derived } \\
\text { GBM cells } \\
\text { (OSU-2) }\end{array}$ & $\begin{array}{l}\text { Complex interplay of mechanics, chemistry, } \\
\text { and topography on glioma migration }\end{array}$ & $\begin{array}{l}\text { Rao et al. } \\
\text { 2013b) }\end{array}$ \\
\hline
\end{tabular}

To mimic brain extracellular matrix (ECM)

\begin{tabular}{|c|c|c|c|c|c|c|}
\hline \multirow{7}{*}{$\begin{array}{l}\text { ECM } \\
\text { properties- } \\
\text { mimetics }\end{array}$} & $\begin{array}{l}\text { Dimensional } \\
\text { effect }\end{array}$ & $\begin{array}{l}\text { Chitosan-alginate }(\mathrm{CA}) \\
\text { scaffolds }\end{array}$ & $\begin{array}{l}\text { Ionic crosslinking of } \\
\text { Iyophilized CA mixture }\end{array}$ & $\begin{array}{l}\text { C6 rat glioma, } \\
\text { U87, U118 }\end{array}$ & $\begin{array}{l}\text { Higher malignancy of 3D cultured } \\
\text { GBM than two-dimensional }\end{array}$ & $\begin{array}{l}\text { Kievit } \\
\text { et al. (2010) }\end{array}$ \\
\hline & & $\begin{array}{l}\text { Collagen-agarose } \\
\text { hydrogels }\end{array}$ & Physically blended mixture & $\begin{array}{l}\text { U373 glioma } \\
\text { spheroids }\end{array}$ & $\begin{array}{l}\text { Mechanosensitivity to ECM-based } \\
\text { biophysical cues }\end{array}$ & $\begin{array}{l}\text { Ulrich } \\
\text { et al. (2010) }\end{array}$ \\
\hline & $\begin{array}{l}\text { Matrix } \\
\text { degradability/ } \\
\text { stiffness/pore } \\
\text { size }\end{array}$ & $\begin{array}{l}\text { Multi-arm based } \\
\text { polyethylene } \\
\text { glycol with matrix } \\
\text { metalloprotease } \\
\text { (MMP)-cleavable } \\
\text { peptide }\end{array}$ & UV photocrosslinking & U87 & $\begin{array}{l}\text { Effects of matrix stiffness on ECM } \\
\text { deposition and remodeling through } \\
\text { modulating HA synthases or MMPs }\end{array}$ & $\begin{array}{l}\text { Wang et al. } \\
(2014,2017)\end{array}$ \\
\hline & & $\begin{array}{l}\text { Gelatin methacrylate } \\
\text { (GelMA) }\end{array}$ & UV photocrosslinking & U87 & $\begin{array}{l}\text { Impact of biophysical properties } \\
\text { (matrix density, crosslinking density, } \\
\text { and degradability) on glioma phenotype }\end{array}$ & $\begin{array}{l}\text { Pedron } \\
\text { et al. (2013) }\end{array}$ \\
\hline & & Polyacrylamide (PA) & $\begin{array}{l}\text { Polymerization with APS, } \\
\text { TEMED }\end{array}$ & U373, U87 & $\begin{array}{l}\text { Impact of microenvironmental stiffness } \\
\text { on GBM proliferation }\end{array}$ & $\begin{array}{l}\text { Ulrich et al. } \\
\text { (2009) and } \\
\text { Umesh et al. (2014) }\end{array}$ \\
\hline & & $\begin{array}{l}\text { Adhesion peptide } \\
\text { (RGD)-functionalized } \\
\text { HA-methacrylate } \\
\text { (Me-HA) }\end{array}$ & $\begin{array}{l}\text { Control of degree of } \\
\text { methacrylation at varying } \\
\text { ratios of thiols }\end{array}$ & $\begin{array}{l}\text { U373, U87, C6 } \\
\text { rat glioma }\end{array}$ & $\begin{array}{l}\text { Matrix stiffness-dependent cell adhesion } \\
\text { (spreading), cell speed, cell growth, } \\
\text { and cell invasion }\end{array}$ & $\begin{array}{l}\text { Ananthanarayanan } \\
\text { et al. (2011) }\end{array}$ \\
\hline & & $\begin{array}{l}\text { Hyaluronic acid- } \\
\text { methacrylate }(\mathrm{Me}-\mathrm{HA})\end{array}$ & $\begin{array}{l}\text { Functionalization of } \mathrm{HA} \text { with } \\
\text { methacrylic anhydride }\end{array}$ & U373, U87 & $\begin{array}{l}\text { CD44-mediated cell adhesion, motility, } \\
\text { and invasion in stiffness-dependent } \\
\text { manner }\end{array}$ & $\begin{array}{l}\text { Kim and Kumar } \\
\text { (2014) }\end{array}$ \\
\hline
\end{tabular}


TABLE 1 | Continued

\begin{tabular}{|c|c|c|c|c|c|}
\hline & Biomaterials & Techniques & Cells & Findings & Reference \\
\hline \multirow[t]{4}{*}{ ECM components-mimetics } & $\begin{array}{l}\text { Adhesion peptide } \\
\text { (RGD)-functionalized } \\
\text { HA-methacrylate } \\
\text { (Me-HA) }\end{array}$ & $\begin{array}{l}\text { Michael-type addition with } \\
\text { dithiothreitol }\end{array}$ & $\begin{array}{l}\text { U373, U87, C6 } \\
\text { rat glioma }\end{array}$ & $\begin{array}{l}\text { Mechanobiological regulation on brain } \\
\text { tumor progression, elevated invasion by } \\
\text { CD44-mediated HA }\end{array}$ & $\begin{array}{l}\text { Ananthanarayanan } \\
\text { et al. (2011) and Kim } \\
\text { and Kumar (2014) }\end{array}$ \\
\hline & $\begin{array}{l}\text { Collagen I, III, or IV } \\
\text { with thiolated HA }\end{array}$ & $\begin{array}{l}\text { Interpenetrating polymer } \\
\text { network }\end{array}$ & $\begin{array}{l}\text { Patient-derived } \\
\text { GBM cells } \\
\text { (OSU-2) }\end{array}$ & $\begin{array}{l}\text { Influence of collagen types on GBM } \\
\text { morphology, HA-dependent GBM } \\
\text { spreading and migration }\end{array}$ & Rao et al. (2013a) \\
\hline & Collagen I-HA & $\begin{array}{l}\text { Semi-interpenetrating } \\
\text { polymer network }\end{array}$ & $\begin{array}{l}\text { Patient-derived } \\
\text { GBM cells } \\
\text { (GSC11) }\end{array}$ & $\begin{array}{l}\text { HA-induced GBM invasion and } \\
\text { associated mechanisms }\end{array}$ & Cha et al. (2016) \\
\hline & $\begin{array}{l}\text { HA-MA functionalized } \\
\text { GelMA }\end{array}$ & Photocrosslinking & U87 (+EGFR) & $\begin{array}{l}\text { HA-induced GBM malignancy and } \\
\text { effects of HA-gradated heterotypic } \\
\text { tumor microenvironment }\end{array}$ & $\begin{array}{l}\text { Pedron et al. (2013, } \\
\text { 2015) }\end{array}$ \\
\hline \multicolumn{6}{|c|}{ Hybrid scaffolds to mimic the GBM microenvironment } \\
\hline \multicolumn{6}{|l|}{ Combinations } \\
\hline \multicolumn{2}{|c|}{ HA matrices + fibrous structures } & $\begin{array}{l}\text { 3D configuration of } \\
\text { collagen-HA semi- } \\
\text { interpenetrating polymer } \\
\text { network on electrospun } \\
\text { fibers }\end{array}$ & $\begin{array}{l}\text { Patient-derived } \\
\text { GBM cells } \\
\text { (GSC11) }\end{array}$ & $\begin{array}{l}\text { Microenvironmental adaptations in } \\
\text { response to drug treatment }\end{array}$ & Cha et al. (2016) \\
\hline \multicolumn{2}{|c|}{ Hydrogel stiffness + HA contents } & $\begin{array}{l}\text { Photocrosslinking, of } \\
\text { GelMA + HAMA in } \\
\text { concentration-dependent } \\
\text { manner }\end{array}$ & U251 & $\begin{array}{l}\text { Coordinated effect of matrix stiffness, } \\
\text { immobilized HA, and compensatory } \\
\text { HA production on GBM invasion }\end{array}$ & Chen et al. (2017) \\
\hline \multicolumn{2}{|c|}{ Vascular basement + HA surfaces (tissue interface) } & $\begin{array}{l}\text { Interfacial culture between } \\
\text { fibronectin-coated PA and } \\
\text { HAMA }\end{array}$ & U373, U87 & $\begin{array}{l}\text { Mechanochemical feedback at the } \\
\text { tissue interfaces }\end{array}$ & Rape et al. (2014) \\
\hline \multicolumn{2}{|c|}{$\begin{array}{l}\text { GBM-endothelial cell coculture (GBM perivascular } \\
\text { niche) }\end{array}$} & $\begin{array}{l}\text { Photocrosslinking, of } \\
\text { GelMA + HAMA }\end{array}$ & $\begin{array}{l}\text { U87, HUVECs, } \\
\text { NHLF }\end{array}$ & $\begin{array}{l}\text { Contribution of perivascular niche to } \\
\text { GBM invasion }\end{array}$ & $\begin{array}{l}\text { Ngo and Harley } \\
(2017)\end{array}$ \\
\hline
\end{tabular}

Umesh et al., 2014), have been performed to examine the role of mechanobiological regulation in GBM invasion. For investigating mechanosensing characteristics of GBM cells, the modified forms of HA gels, such as HA-methacrylate (Me-HA) or RGDfunctionalized Me-HA (Ananthanarayanan et al., 2011; Kim and Kumar, 2014), were used to control the matrix stiffness, observing the stiffness-dependent GBM features via CD44-mediated mechanosensing.

\section{Matrices to Mimic the ECM Components}

Hyaluronic acid, which is a major ECM component in tumorous brain, is a linear chain composed of D-glucuronic acid and $\mathrm{N}$-acetyl-D-glucosamine, so it is hard to form cross-linked network itself. Therefore, to investigate the role of HA in GBM invasion, the HA is chemically modified so that it is cross-linked. Chemically modified forms of HA hydrogels include thiolated HA (Rao et al., 2013a), methacrylated HA (Ananthanarayanan et al., 2011; Kim and Kumar, 2014), and mixtures with GelMA (Pedron et al., 2013). GBM cells are strongly influenced by the HA concentration and show increased invasion via CD44-mediated HA adhesion (Kim and Kumar, 2014).

Physical blending with other cross-linkable hydrogels, such as collagen, is another means of incorporating HA components into ECM-mimetic model system. By creating interpenetrating polymer networks with HA solution and collagen gels, HA-rich matrices can be created (Yang et al., 2011; Rao et al., 2013a; Cha et al., 2016). Within this HA-rich matric, GBM develops highly proliferative, invasive phenotypes (Cha et al., 2016). These results have been confirmed using other HA-rich matrices, such as GelMA-based HA-rich matrices (Pedron et al., 2015, 2017), which have in vivo-like characteristics.

Various GAG-based components, such as heparin, chondroitin sulfate, and keratin sulfate, are often incorporated within the ECM of tumorous brain as the scaffolding components. Tenascin-C (Sarkar et al., 2006) and chondroitin sulfate (Yang et al., 2011; Logun et al., 2016) have been incorporated into collagen hydrogels to investigate their influence on the GBM invasion. As expected, the motility of GBM was increased by higher concentrations of both GAGs.

For advanced brain ECM-mimetic model system, decellularized matrix, obtained by isolating the ECM scaffold of an original tissue (Gilbert et al., 2006), shows utility for recreating the ECM components of GBM tissue. Using porcine brain tissue, decellularized ECM was applied to mimic the brain matrices (DeQuach et al., 2011), further indicating the potential of mimicking the tumorous ECM to investigate GBM invasion. 


\section{Hybrid Scaffolds for GBM Microenvironment}

Recently, researchers have focused on integrating multiple components of GBM microenvironment to reproduce conditions corresponding more closely to in vivo conditions. As mentioned earlier, by controlling the various design parameters of ECM matrices, the combined effects of the chemical and mechanical properties of the ECM on GBM invasion were revealed (Chen et al., 2017). Moreover, our group developed 3D GBM models consisting of HA matrices and fibrous structures arranged in a 3D configuration. Using such integrated systems, microenvironmental adaptation was observed during GBM invasion (Cha et al., 2016); changes in the GBM invasion of the HA matrices were mediated by the focal adhesion kinase and MMP, within the fibrous structures, in response to blockade of a HA-mediated pathway of GBM invasion. Recently, other cellular components in the microenvironment were incorporated into 3D GBM models, revealing the roles of glial cells and the perivascular niche in GBM invasion (Grodecki et al., 2015; Iwadate et al., 2016; Gritsenko et al., 2017; Ngo and Harley, 2017).

\section{FURTHER DIRECTION FOR IN VITRO GBM MODELS}

In recent decades, the focus of cancer treatment has shifted markedly, from targeting cancer itself to understanding its microenvironment; this is because an aberrant microenvironment is pivotal to cancerous tumor progression (Joyce and Pollard, 2009). As suggested in seed-and-soil hypothesis (Fidler, 2003), a favorable environment for the metastatic cancer is crucial for enabling cells to settle down and mature. Indeed, cancers reside in complex tissue environments, including stromal cells, blood vessels, immune cells, and the ECM, which strongly influence the sustained growth, invasion, and metastasis of cancer (Gilkes et al., 2014). During tumor progression, cancer cells remodel dynamically and interact reciprocally with their microenvironment (both the cellular and non-cellular components), leading to the formation of a tumor-favorable environment (Quail and Joyce, 2013). Many recent studies have highlighted the importance of targeting tumor microenvironment to reduce tumor malignancy (Cuddapah et al., 2014; Hambardzumyan and Bergers, 2015; Xiao et al., 2017). For further progress in the development of in vitro GBM models, the other components of brain tumor microenvironment should be considered to better understand glioblastoma invasion.

\section{Intratumoral Heterogeneity}

Solid tumors have mass transport limitations due to their decreased surface-area-to-volume ratios and longer diffusion lengths. Owing to this limitation in diffusion, the tumor mass develops internal hypoxic areas, causing shortages of oxygen and nutrients. Tumor hypoxia is one of the key factors inducing the development of heterogeneous cell subpopulation within the tumor masses, which leads to an aggressive treatment-resistant phenotype, rapid progression, and poor prognosis (Heddleston et al., 2009; Li and Rich, 2010; Cheng et al., 2011). Recent studies have reported that these subcellular populations within the GBM mass are cancer stem cells, which exhibit increased tumorigenicity and stem cell-like capacity (Hubert et al., 2016). Histologically, GBM tissue contains a large hypoxic core, called pseudopalisading necrosis (Rong et al., 2006), which in turn contains a stem-like subpopulation (Mamun et al., 2009). Due to its greater therapeutic resistance compared with other tumor population, the roles of cancer stem cells in GBM progression should be considered.

\section{Interaction with Surrounding Cells}

Along with cancerous astrocytoma cells, GBM tissues contain other tumor-associated parenchymal cells such as glial cells, vascular cells, microglia, peripheral immune cells, and neural precursor cells. These all play crucial influencing roles in the pathology of GBM (Rape et al., 2014). For example, when activated, astrocytes in GBM tissue promote tumor progression within the GBM microenvironment (Hu et al., 2017). Moreover, the neural vasculature provides a perivascular bed not only for GBM but also for stem-like GBM cells (Bao et al., 2006; Johansson et al., 2017). In addition, microglial cells, which can comprise up to $30 \%$ of the brain tumor mass, are heavily involved in GBM invasion (Hambardzumyan et al., 2016). Therefore, by cocultivating these surrounding cells, we can investigate the supportive roles of tumor-associated cells on GBM progression.

\section{Application: In Vitro GBM Models As High-Throughput Platforms}

By integrating and incorporating the complex components of GBM microenvironment, the model presented herein should be used as a drug-testing tool for GBM patients. For example, by using patient-derived cells and matrices, personalized treatment plans can be constructed. Since the biomimetic approaches used to model the GBM microenvironment contribute to enhancing the similarity and reliability for in vivo GBM cells, anti-invasive therapies could be evaluated in a high-throughput manner.

\section{CONCLUSION}

This review offers an overview of recent development in in vitro GBM models in their microenvironmental context and their further perspectives. Using these biomimetic models, we can investigate and evaluate the invasive features of GBM cells, consequently providing the drug test platform to target their invasion. In the future, we thus expect that the integration of multiple components from complex microenvironment will enhance the understanding of GBM biology and further suggestion of effective therapeutics for the GBM patients.

\section{AUTHOR CONTRIBUTIONS}

JC and PK planned and wrote the manuscript of this mini review.

\section{FUNDING}

This research was supported from the National Research Foundation of Korea (NRF) (grant number: NRF-2015H1A2A1030560 and NRF-2016R1E1A1A01943393) and by a grant of the Korea 
Health Technology R\&D Project through the Korea Health Industry Development Institute (KHIDI), funded by the Ministry of Health \& Welfare, Republic of Korea (grant number:

\section{REFERENCES}

Agudelo-Garcia, P. A., De Jesus, J. K., Williams, S. P., Nowicki, M. O., Chiocca, E. A., Liyanarachchi, S., et al. (2011). Glioma cell migration on three-dimensional nanofiber scaffolds is regulated by substrate topography and abolished by inhibition of STAT3 signaling. Neoplasia 13, 831-840. doi:10.1593/neo.11612

Ananthanarayanan, B., Kim, Y., and Kumar, S. (2011). Elucidating the mechanobiology of malignant brain tumors using a brain matrix-mimetic hyaluronic acid hydrogel platform. Biomaterials 32, 7913-7923. doi:10.1016/j. biomaterials.2011.07.005

Bao, S., Wu, Q., Sathornsumetee, S., Hao, Y., Li, Z., Hjelmeland, A. B., et al. (2006). Stem cell-like glioma cells promote tumor angiogenesis through vascular endothelial growth factor. Cancer Res. 66, 7843-7848. doi:10.1158/0008-5472. CAN-06-1010

Beliveau, A., Thomas, G., Gong, J., Wen, Q., and Jain, A. (2016). Aligned nanotopography promotes a migratory state in glioblastoma multiforme tumor cells. Sci. Rep. 6, 26143. doi:10.1038/srep26143

Bellail, A. C., Hunter, S. B., Brat, D. J., Tan, C., and Van Meir, E. G. (2004). Microregional extracellular matrix heterogeneity in brain modulates glioma cell invasion. Int. J. Biochem. Cell Biol. 36, 1046-1069. doi:10.1016/j.biocel. 2004.01.013

Cha, J., Kang, S. G., and Kim, P. (2016). Strategies of mesenchymal invasion of patient-derived brain tumors: microenvironmental adaptation. Sci. Rep. 6, 24912. doi:10.1038/srep24912

Cha, J., Koh, I., Choi, Y., Lee, J., Choi, C., and Kim, P. (2015). Tapered microtract array platform for antimigratory drug screening of human glioblastoma multiforme. Adv. Healthc. Mater. 4, 405-411. doi:10.1002/adhm.201400384

Chen, J. E., Pedron, S., and Harley, B. A. C. (2017). The combined influence of hydrogel stiffness and matrix-bound hyaluronic acid content on glioblastoma invasion. Macromol. Biosci. 17. doi:10.1002/mabi.201700018

Cheng, L., Wu, Q., Guryanova, O. A., Huang, Z., Huang, Q., Rich, J. N., et al. (2011). Elevated invasive potential of glioblastoma stem cells. Biochem. Biophys. Res. Commun. 406, 643-648. doi:10.1016/j.bbrc.2011.02.123

Cuddapah, V. A., Robel, S., Watkins, S., and Sontheimer, H. (2014). A neurocentric perspective on glioma invasion. Nat. Rev. Neurosci. 15, 455-465. doi:10.1038/ nrn3765

DeQuach, J. A., Yuan, S. H., Goldstein, L. S., and Christman, K. L. (2011). Decellularized porcine brain matrix for cell culture and tissue engineering scaffolds. Tissue Eng. Part A 17, 2583-2592. doi:10.1089/ten.TEA.2010.0724

Dziurzynski, K., Blas-Boria, D., Suki, D., Cahill, D. P., Prabhu, S. S., Puduvalli, V., et al. (2012). Butterfly glioblastomas: a retrospective review and qualitative assessment of outcomes. J. Neurooncol. 109, 555-563. doi:10.1007/ s11060-012-0926-0

Fidler, I. J. (2003). The pathogenesis of cancer metastasis: the 'seed and soil' hypothesis revisited. Nat. Rev. Cancer 3, 453-458. doi:10.1038/nrc1098

Friedl, P., and Alexander, S. (2011). Cancer invasion and the microenvironment: plasticity and reciprocity. Cell 147, 992-1009. doi:10.1016/j.cell.2011.11.016

Gilbert, T. W., Sellaro, T. L., and Badylak, S. F. (2006). Decellularization of tissues and organs. Biomaterials 27, 3675-3683. doi:10.1016/j.biomaterials.2006.02.014

Gilkes, D. M., Semenza, G. L., and Wirtz, D. (2014). Hypoxia and the extracellular matrix: drivers of tumour metastasis. Nat. Rev. Cancer 14, 430-439. doi:10.1038/ $\operatorname{nrc} 3726$

Gladson, C. L. (1999). The extracellular matrix of gliomas: modulation of cell function. J. Neuropathol. Exp. Neurol. 58, 1029-1040. doi:10.1097/ 00005072-199910000-00001

Gritsenko, P., Leenders, W., and Friedl, P. (2017). Recapitulating in vivo-like plasticity of glioma cell invasion along blood vessels and in astrocyte-rich stroma. Histochem. Cell Biol. 148, 395-406. doi:10.1007/s00418-017-1604-2

Gritsenko, P. G., Ilina, O., and Friedl, P. (2012). Interstitial guidance of cancer invasion. J. Pathol. 226, 185-199. doi:10.1002/path.3031

Grodecki, J., Short, A. R., Winter, J. O., Rao, S. S., Winter, J. O., Otero, J. J., et al. (2015). Glioma-astrocyte interactions on white matter tract-mimetic aligned electrospun nanofibers. Biotechnol. Prog. 31, 1406-1415. doi:10.1002/btpr.2123
HI14C1324). We also appreciate the financial support from the Ministry of Science ICT and Future Planning, Republic of Korea (grant number: 2016M3A9B4915823).

Hambardzumyan, D., and Bergers, G. (2015). Glioblastoma: defining tumor niches. Trends Cancer 1, 252-265. doi:10.1016/j.trecan.2015.10.009

Hambardzumyan, D., Gutmann, D. H., and Kettenmann, H. (2016). The role of microglia and macrophages in glioma maintenance and progression. Nat. Neurosci. 19, 20-27. doi:10.1038/nn.4185

Heddleston, J. M., Li, Z., McLendon, R. E., Hjelmeland, A. B., and Rich, J. N. (2009). The hypoxic microenvironment maintains glioblastoma stem cells and promotes reprogramming towards a cancer stem cell phenotype. Cell Cycle 8, 3274-3284. doi:10.4161/cc.8.20.9701

Holland, E. C. (2000). Glioblastoma multiforme: the terminator. Proc. Natl. Acad. Sci. U.S.A. 97, 6242-6244. doi:10.1073/pnas.97.12.6242

Hu, B., Emdad, L., Kegelman, T. P., Shen, X. N., Das, S. K., Sarkar, D., et al. (2017). Astrocyte elevated gene-1 regulates beta-catenin signaling to maintain glioma stem-like stemness and self-renewal. Mol. Cancer Res. 15, 225-233. doi:10.1158/1541-7786.MCR-16-0239

Hubert, C. G., Rivera, M., Spangler, L. C., Wu, Q., Mack, S. C., Prager, B. C., et al. (2016). A three-dimensional organoid culture system derived from human glioblastomas recapitulates the hypoxic gradients and cancer stem cell heterogeneity of tumors found in vivo. Cancer Res. 76, 2465-2477. doi:10.1158/00085472.CAN-15-2402

Iwadate, Y., Fukuda, K., Matsutani, T., and Saeki, N. (2016). Intrinsic protective mechanisms of the neuron-glia network against glioma invasion. J. Clin. Neurosci. 26, 19-25. doi:10.1016/j.jocn.2015.07.024

Jin, S. G., Jeong, Y. I., Jung, S., Ryu, H. H., Jin, Y. H., and Kim, I. Y. (2009). The effect of hyaluronic acid on the invasiveness of malignant glioma cells: comparison of invasion potential at hyaluronic acid hydrogel and matrigel. J. Korean Neurosurg. Soc. 46, 472-478. doi:10.3340/jkns.2009.46.5.472

Johansson, E., Grassi, E. S., Pantazopoulou, V., Tong, B., Lindgren, D., Berg, T. J., et al. (2017). CD44 interacts with HIF-2alpha to modulate the hypoxic phenotype of perinecrotic and perivascular glioma cells. Cell Rep. 20, 1641-1653. doi:10.1016/j.celrep.2017.07.049

Johnson, J., Nowicki, M. O., Lee, C. H., Chiocca, E. A., Viapiano, M. S., Lawler, S. E. et al. (2009). Quantitative analysis of complex glioma cell migration on electrospun polycaprolactone using time-lapse microscopy. Tissue Eng. Part C Methods 15, 531-540. doi:10.1089/ten.TEC.2008.0486

Joyce, J. A., and Pollard, J. W. (2009). Microenvironmental regulation of metastasis. Nat. Rev. Cancer 9, 239-252. doi:10.1038/nrc2618

Kievit, F. M., Florczyk, S. J., Leung, M. C., Veiseh, O., Park, J. O., Disis, M. L., et al. (2010). Chitosan-alginate 3D scaffolds as a mimic of the glioma tumor microenvironment. Biomaterials 31, 5903-5910. doi:10.1016/j.biomaterials.2010.03.062

Kim, Y., and Kumar, S. (2014). CD44-mediated adhesion to hyaluronic acid contributes to mechanosensing and invasive motility. Mol. Cancer Res. 12, 1416-1429. doi:10.1158/1541-7786.MCR-13-0629

Lau, L. W., Cua, R., Keough, M. B., Haylock-Jacobs, S., and Yong, V. W. (2013). Pathophysiology of the brain extracellular matrix: a new target for remyelination. Nat. Rev. Neurosci. 14, 722-729. doi:10.1038/nrn3550

Li, Z., and Rich, J. N. (2010). Hypoxia and hypoxia inducible factors in cancer stem cell maintenance. Curr. Top. Microbiol. Immunol. 345, 21-30. doi:10.1007/82_2010_75

Logun, M. T., Bisel, N. S., Tanasse, E. A., Zhao, W., Gunasekera, B., Mao, L., et al. (2016). Glioma cell invasion is significantly enhanced in composite hydrogel matrices composed of chondroitin 4- and 4,6-sulfated glycosaminoglycans. J. Mater. Chem. B Mater. Biol. Med. 4, 6052-6064. doi:10.1039/C6TB01083K

Louis, D. N. (2006). Molecular pathology of malignant gliomas. Annu. Rev. Pathol. 1, 97-117. doi:10.1146/annurev.pathol.1.110304.100043

Louis, D. N., Perry, A., Reifenberger, G., von Deimling, A., Figarella-Branger, D., Cavenee, W. K., et al. (2016). The 2016 World Health Organization classification of tumors of the central nervous system: a summary. Acta Neuropathol. 131, 803-820. doi:10.1007/s00401-016-1545-1

Mamun, M. H., Kamitani, H., Kinoshita, Y., Tabuchi, S., Wasita, B., and Watanabe, T. (2009). Cerebral ischemia promotes rich pseudopalisading necrosis in the rat c6 glioblastoma model. Neurol. Med. Chir. (Tokyo) 49, 294-299. doi:10.2176/ nmc.49.294 
Miyata, S., and Kitagawa, H. (2017). Formation and remodeling of the brain extracellular matrix in neural plasticity: roles of chondroitin sulfate and hyaluronan. Biochim. Biophys. Acta 1861, 2420-2434. doi:10.1016/j.bbagen. 2017.06.010

Munson, J. M., Bellamkonda, R. V., and Swartz, M. A. (2013). Interstitial flow in a 3D microenvironment increases glioma invasion by a CXCR4-dependent mechanism. Cancer Res. 73, 1536-1546. doi:10.1158/0008-5472.CAN-12-2838

Ngo, M. T., and Harley, B. A. (2017). The influence of hyaluronic acid and glioblastoma cell coculture on the formation of endothelial cell networks in gelatin hydrogels. Adv. Healthc. Mater. doi:10.1002/adhm.201700687

Pedron, S., Becka, E., and Harley, B. A. (2013). Regulation of glioma cell phenotype in 3D matrices by hyaluronic acid. Biomaterials 34, 7408-7417. doi:10.1016/j. biomaterials.2013.06.024

Pedron, S., Becka, E., and Harley, B. A. (2015). Spatially gradated hydrogel platform as a 3D engineered tumor microenvironment. Adv. Mater. 27, 1567-1572. doi:10.1002/adma.201404896

Pedron, S., Hanselman, J. S., Schroeder, M. A., Sarkaria, J. N., and Harley, B. A. C. (2017). Extracellular hyaluronic acid influences the efficacy of EGFR tyrosine kinase inhibitors in a biomaterial model of glioblastoma. Adv. Healthc. Mater. doi:10.1002/adhm.201700529

Pedron, S., and Harley, B. A. (2013). Impact of the biophysical features of a 3D gelatin microenvironment on glioblastoma malignancy. J. Biomed. Mater. Res. A 101, 3404-3415. doi:10.1002/jbm.a.34637

Quail, D. F., and Joyce, J. A. (2013). Microenvironmental regulation of tumor progression and metastasis. Nat. Med. 19, 1423-1437. doi:10.1038/nm.3394

Rao, J. S. (2003). Molecular mechanisms of glioma invasiveness: the role of proteases. Nat. Rev. Cancer 3, 489-501. doi:10.1038/nrc1121

Rao, S. S., Dejesus, J., Short, A. R., Otero, J. J., Sarkar, A., and Winter, J. O. (2013a). Glioblastoma behaviors in three-dimensional collagen-hyaluronan composite hydrogels. ACS Appl. Mater. Interfaces 5, 9276-9284. doi:10.1021/am402097j

Rao, S. S., Nelson, M. T., Xue, R., DeJesus, J. K., Viapiano, M. S., Lannutti, J. J., et al. (2013b). Mimicking white matter tract topography using core-shell electrospun nanofibers to examine migration of malignant brain tumors. Biomaterials 34, 5181-5190. doi:10.1016/j.biomaterials.2013.03.069

Rao, S. S., Lannutti, J. J., Viapiano, M. S., Sarkar, A., and Winter, J. O. (2014). Toward $3 \mathrm{D}$ biomimetic models to understand the behavior of glioblastoma multiforme cells. Tissue Eng. Part B Rev. 20, 314-327. doi:10.1089/ten.TEB.2013.0227

Rape, A., Ananthanarayanan, B., and Kumar, S. (2014). Engineering strategies to mimic the glioblastoma microenvironment. Adv. Drug Deliv. Rev. 7, 172-183. doi:10.1016/j.addr.2014.08.012

Rape, A. D., and Kumar, S. (2014). A composite hydrogel platform for the dissection of tumor cell migration at tissue interfaces. Biomaterials 35, 8846-8853. doi:10.1016/j.biomaterials.2014.07.003

Rong, Y., Durden, D. L., Van Meir, E. G., and Brat, D. J. (2006). 'Pseudopalisading' necrosis in glioblastoma: a familiar morphologic feature that links vascular pathology, hypoxia, and angiogenesis. J. Neuropathol. Exp. Neurol. 65, 529-539. doi:10.1097/00005072-200606000-00001

Sarkar, S., Nuttall, R. K., Liu, S., Edwards, D. R., and Yong, V. W. (2006). Tenascin-C stimulates glioma cell invasion through matrix metalloproteinase-12. Cancer Res. 66, 11771-11780. doi:10.1158/0008-5472.CAN-05-0470

Sharma, P., Sheets, K., Elankumaran, S., and Nain, A. S. (2013). The mechanistic influence of aligned nanofibers on cell shape, migration and blebbing dynamics of glioma cells. Integr. Biol. (Camb.) 5, 1036-1044. doi:10.1039/c3ib40073e

Sim, W., Cha, J., Choi, C., and Choi, K. (2017). Rapid and quantitative measurement of cell adhesion and migration activity by time-series analysis on biomimetic topography. Biotechnol. Bioprocess Eng. 22, 107-113. doi:10.1007/ s12257-016-0625-3
Smith, C. L., Kilic, O., Schiapparelli, P., Guerrero-Cazares, H., Kim, D. H., SedoraRoman, N. I., et al. (2016). Migration phenotype of brain-cancer cells predicts patient outcomes. Cell Rep. 15, 2616-2624. doi:10.1016/j.celrep.2016.05.042

Stummer, W., Pichlmeier, U., Meinel, T., Wiestler, O. D., Zanella, F., Reulen, H. J., et al. (2006). Fluorescence-guided surgery with 5-aminolevulinic acid for resection of malignant glioma: a randomised controlled multicentre phase III trial. Lancet Oncol. 7, 392-401. doi:10.1016/S1470-2045(06)70665-9

Stupp, R., Mason, W. P., van den Bent, M. J., Weller, M., Fisher, B., Taphoorn, M. J., et al. (2005). Radiotherapy plus concomitant and adjuvant temozolomide for glioblastoma. N. Engl. J. Med. 352, 987-996. doi:10.1056/NEJMoa043330

Ulrich, T. A., de Juan Pardo, E. M., and Kumar, S. (2009). The mechanical rigidity of the extracellular matrix regulates the structure, motility, and proliferation of glioma cells. Cancer Res. 69, 4167-4174. doi:10.1158/0008-5472.CAN-08-4859

Ulrich, T. A., Jain, A., Tanner, K., MacKay, J. L., and Kumar, S. (2010). Probing cellular mechanobiology in three-dimensional culture with collagen-agarose matrices. Biomaterials 31, 1875-1884. doi:10.1016/j.biomaterials.2009.10.047

Umesh, V., Rape, A. D., Ulrich, T. A., and Kumar, S. (2014). Microenvironmental stiffness enhances glioma cell proliferation by stimulating epidermal growth factor receptor signaling. PLoS ONE 9:e101771. doi:10.1371/journal.pone.0101771

Wang, C., Tong, X., Jiang, X., and Yang, F. (2017). Effect of matrix metalloproteinase-mediated matrix degradation on glioblastoma cell behavior in 3D PEG-based hydrogels. J. Biomed. Mater. Res. A 105, 770-778. doi:10.1002/ jbm.a. 35947

Wang, C., Tong, X., and Yang, F. (2014). Bioengineered 3D brain tumor model to elucidate the effects of matrix stiffness on glioblastoma cell behavior using PEG-based hydrogels. Mol. Pharm. 11, 2115-2125. doi:10.1021/mp5000828

Wang, H., Xu, T., Jiang, Y., Xu, H., Yan, Y., Fu, D., et al. (2015). The challenges and the promise of molecular targeted therapy in malignant gliomas. Neoplasia 17, 239-255. doi:10.1016/j.neo.2015.02.002

Xiao, W., Sohrabi, A., and Seidlits, S. K. (2017). Integrating the glioblastoma microenvironment into engineered experimental models. Future Sci. OA 3, FSO189. doi:10.4155/fsoa-2016-0094

Yang, Y. L., Motte, S., and Kaufman, L. J. (2010). Pore size variable type I collagen gels and their interaction with glioma cells. Biomaterials 31, 5678-5688. doi:10.1016/j.biomaterials.2010.03.039

Yang, Y. L., Sun, C., Wilhelm, M. E., Fox, L. J., Zhu, J., and Kaufman, L. J. (2011). Influence of chondroitin sulfate and hyaluronic acid on structure, mechanical properties, and glioma invasion of collagen I gels. Biomaterials 32, 7932-7940. doi:10.1016/j.biomaterials.2011.07.018

Yip, S., Miao, J., Cahill, D. P., Iafrate, A. J., Aldape, K., Nutt, C. L., et al. (2009). MSH6 mutations arise in glioblastomas during temozolomide therapy and mediate temozolomide resistance. Clin. Cancer Res. 15, 4622-4629. doi:10.1158/10780432.CCR-08-3012

Zhu, B., Zhang, Q., Lu, Q., Xu, Y., Yin, J., Hu, J., et al. (2004). Nanotopographical guidance of C6 glioma cell alignment and oriented growth. Biomaterials 25, 4215-4223. doi:10.1016/j.biomaterials.2003.11.020

Conflict of Interest Statement: The authors declare that the research was conducted in the absence of any commercial or financial relationships that could be construed as a potential conflict of interest.

Copyright (๑) 2017 Cha and Kim. This is an open-access article distributed under the terms of the Creative Commons Attribution License (CC BY). The use, distribution or reproduction in other forums is permitted, provided the original author(s) or licensor are credited and that the original publication in this journal is cited, in accordance with accepted academic practice. No use, distribution or reproduction is permitted which does not comply with these terms. 